\title{
PENINGKATAN HASIL BELAJAR PESERTA DIDIK KELAS X SMK NEGERI 6 AMBON MENGGUNAKAN MODEL PEMBELAJARAN KOOPERATIF TIPE NUMBERED HEADS TOGETHER (NHT) DENGAN MEDIA FLASH PLAYER PADA MATERI IKATAN KIMIA
}

\author{
Natalia Hingzty de Sirat ${ }^{1}$, C.S. Ayal ${ }^{2}$, dan Y. Manoppo ${ }^{1}$ \\ ${ }^{1}$ Departement of Chemistry-FKIP, Pattimura University Ambon \\ ${ }^{2}$ Departement of Mathematics-FKIP, Pattimura University Ambon
}

Diterima 23 Oktober 2018/Disetujui 28 November 2018

\begin{abstract}
This study aims to determine the increase in learning outcomes of students of SMK Negeri 6 Ambon by using the NHT coopertive learning model (Numbered Heads Together) with Flash Player media. The purpose of this research was to determine the improvement of learning outcomes in the chemical bonding material learning by using the NHT learning model on class X TI-2. This research was conducted with a study sample of 27 students in class X TI-2. Data collection is done by using test instruments and LKPD. The results of data analysis showed that the learning outcomes of class X TI-2 students achieved different qualifications, namely very good qualifications 1 (3.70\%). Good $10(37.04 \%)$, Sufficient $10(37.04 \%)$, less $6(22.22 \%)$. The N-gain achievement data obtained were 18 students $(66.67 \%)$ in the high category and 9 students $(33.33 \%)$ in the moderate gain category, overall the average $n$-gain value was 0.71 meant in the high category. Thus the NHT type cooperative learning model can help improve student learning outcomes.
\end{abstract}

Keywords: Cooperative learning type NHT (Numbered Heats Together) model, Flash Player media, Chemical bonding, Learning Outcomes

\begin{abstract}
ABSTRAK
Penelitian ini bertujuan untuk mengetahui peningkatan hasil belajar peserta didik SMK Negeri 6 Ambon dengan mengunakan model pembelajaran koopertif tipe NHT (Numbered Heads Together) dengan media Flash Player. Tujuan penelitian ini dilakukan adalah untuk mengetahui peningkatan hasil belajar pada materi ikatan kimia yang diajarkan dengan menggunakan model pembelajaran NHT pada kelas X TI-2. Penelitian ini dilakukan dengan sampel penelitian 27 peserta didik kelas X TI-2. Pengumpulan data dilakukan dengan mengunakan instrument tes dan LKPD. Hasil analisis data diperoleh bahwa hasil belajar peserta didik kelas X TI-2 mencapai kualifikasi yang berbeda-beda yaitu pada kualifikasi sangat baik 1 (3,70\%). Baik 10 (37,04\%), Cukup 10 (37,04\%), kurang $6(22,22 \%)$. Data pencapaian N-gain yang diperoleh yaitu 18 peserta didik $(66,67 \%)$ berada pada kategori tinggi dan 9 peserta didik (33,33\%) berada pada kategori gain sedang, secara keseluruhan rata-rata nilai n-gain sebesar 0,71 termaksud pada kategori tinggi. Dengan demikian model pembelajaran kooperati tipe NHT dapat membantu meningkatkan hasil belajar peserta didik.
\end{abstract}

Kata kunci: Model pembelajarn kooperatif tipe NHT (Numbered Heads Together), Media Flash Player, Ikatan Kimia, Hasil Belajar

\section{PENDAHULUAN}

Pendidikan merupakan salah satu faktor penting dalam pembangunan bangsa dan negara sehingga berbagai upaya dilakukan untuk meningkatkan kualitas pendidikan. Salah satu upaya yang dilakukan untuk meningkatkan kualitas pendidikan adalah pemberlakuan dua kurikulum oleh 
Pemerintah (Ika, 2016: 22). Menurut Yussy Tri Muhamad (2014: 40) dalam bukunya Pelaksanaan model pembelajaran Problem Based Learning menyatakan Kurikulum sebagai salah satu unsur yang bisa memberikan kontribusi yang signifikan terhadap proses pembelajaran.

Kurikulum 2013 menganut pandangan dasar bahwa pengetahuan tidak dapat dipindahkan begitu saja dari guru ke peserta didik. Pada setiap proses pembelajaran dibutuhkan suatu model pembelajaran yang sesuai dengan karakteristik pendekatan ilmiah (Yussi 2014: 41). Pengajar memiliki peranan penting menciptakan kondisi belajar yang kondusif agar tujuan pembelajaran dapat tercapai. Pada praktiknya, pengajar dapat menggunakan berbagai media pendukung, metode dan model, serta instrumen penilaian pembelajaran. (Evi, 2016: 87).

Salah satu penggunaan model pembelajaran yang peneliti gunakan adalah pembelajaran kooperatif. Pembelajaran kooperatif menawarkan berbagai jenis metode untuk menggerakan peserta didik untuk ikut serta dalam proses belajar mengajar, sehingga pembelajaran yang berlangsung menjadi pembelajaran yang berpusat pada peserta didik. Metode yang digunakan adalah NHT dikembangkan oleh Spancer Kagan (1992). Metode pembelajaran NHT mengajak peserta didik untuk belajar sambil bermain. Penggunaan metode NHT memberikan waktu yang lebih banyak kepada peserta didik untuk berdiskusi di dalam kelompoknya, peserta didik dapat saling bertukar pikiran satu sama lain (Retnani, 2014: 59).

Hasil observasi awal pada SMK Negeri 6 Ambon didapatkan beberapa kekurangan dalam pembelajaran kimia, yaitu hasil belajar peserta didik pada konsep ikatan kimia masih rendah dengan jumlah presentase kelulusan $43 \%$. oleh karena itu diperlukan Penerapan model pembelajaran dan media untuk mengaktifkan peserta didik sehingga pembelajaran tidak hanya berlangsug satu arah (pihak guru), dan dapat meningkatkan semangat dan minat belajar peserta didik. Berdasarkan latar belakang diatas, penulis tertarik untuk mengadakan penelitian dengan judul "Peningkatan Hasil Belajar Peserta Didik kelas X SMK Negeri 6 Ambon Mengunakan Model Pemelajaran Kooperatif Tipe Numbered Heads Together (NHT) dengan media Flash Player Pada Materi Ikatan Kimia". Penelitian ini diharapkan bisa membantu peserta didik meningkatkan hasil belajar dan bisa membantu guru dalam mengimplementasikan model pembelajaran NHT sekaligus memasyarakatkannya sebagai variasi dalam melakukan proses pembelajaran.

\section{METODE PENELITIAN}

Penelitian ini menggunakan tipe penelitian Deskriptif Kuantitatif. Penelitian ini memusatkan perhatian pada masalah actual sebagaimana adanya pada saat penelitian berlangsung, dengan mengunakan desain one group pretest-posttest design.

Sampel yang di gunakan adalah Peserta didik kelas X SMK N 6 Ambon jurusan Multimedia (TI2) yang berjumlah 27 peserta didik. Instrumen penelitian yang digunakan adalah Instrumen tes, berupa pre test dan post test dalam bentuk pilihan ganda dan uraian; Lembar kerja peserta didik untuk mengukur kemampuan kognitif, afektif dan psikomotor peserta didik.

Tes awal dilakukan dengan tujuan yaitu untuk mengetahui kemampuan awal peserta didik mengenai materi ikatan kimia. Tes awal yang dilakukan bertujuan untuk mengetahui kemampuan awal siswa sebelum mengikuti pembelajaran terhadap konsep yang diajarkan (Arief, 2013: 6). Tes awal terdiri dari 10 soal PG dan 2 soal Essai yang disusun berdasarkan materi yang akan diajarkan yakni Ikatan Ion, Ikatan Kovalen dan Ikatan Logam.

Teknik pengumpulan data yang digunakan adalah teknik tes. Teknik analisa data yang dipakai adalah analisa deskriptif kuantitatif yang dilakukan dalam menganalisa tes hasil belajar Kimia, yakni kognitif Produk, kognitif proses dan n-gain.

\section{HASIL PENELITIAN}


Tujuan penelitian ini adalah untuk mengetahui peningkatan hasil belajar setelah proses pembelajaran dilakukan dengan menggunakan model pembelajaran (Numbered Heads Together) dengan media Flash Player. Penelitian ini dilakukan sebanyak tiga kali pertemuan pada materi lkatan Kimia.

Tabel 1. Data Pencapaian Peserta Didik pada Tes Awal (pre test)

\begin{tabular}{cccc}
\hline Interval & Fekuensi & Frekuensi relative \% & Kualifikasi \\
\hline $90-100$ & - & - & Sangat Baik \\
$81-90$ & - & - & Baik \\
$72-80$ & - & - & Cukup \\
$<72$ & 27 & 100 & Kurang \\
Jumlah & 27 & 100 & \\
\hline
\end{tabular}

Berdasarkan tabel 1 dapat dilihat bahwa kemampuan peserta didik dalam menjawab setiap soal masih rendah yang dibuktikan dengan hasil tes awal peserta didik yang berada ada kualifikasi kurang yang berjumlah 27 peserta didik (100\%), dan tidak ada peserta didik yang berada pada kualifikasi cukup, baik dan sangat baik penyebabnya adalah karena pengetahuan awal terhadap materi ikatan kimia ini masih minim dan kurangnya kesiapan peserta didik sebelum diajarkan konsep ikatan kimia.

Ketidakmampuan peserta didik dalam menjawab soal-soal, sejalan dengan yang dikemukakan oleh Latifah (2008: 2) bahwa "hasil belajar kimia masih rendah tersebut menujukan peserta didik mengalami kesulitan dan belum memahami seutuhnya konsep-konsep kimia. Kesulitan belajar tersebut dikarenakan beberapa konsep yang ada pada mata pelajaran kimia adalah bersifat abstrak" seperti salah satunya adalah ikatan kimia.

Tes akhir pada penelitian ini bertujuan untuk mengetahui kemampuan kognitif peserta didik terhadap konsep ikatan kimia yang diajarkan menggunakan model pembelajaran NHT (Numbered Heads Together), yang dilakukan setelah proses pembelajaran.

Tabel 2. Data Pencapaian Peserta Didik pada Tes Akhir (Post test)

\begin{tabular}{cccc}
\hline Interval & Frekuensi & Frekuensi relative $\%$ & Kualifikasi \\
\hline $91-100$ & 1 & 3,70 & Sangat Baik \\
$81-90$ & 10 & 37,04 & Baik \\
$72-80$ & 10 & 37,04 & Cukup \\
72 & 6 & 22,22 & Kurang \\
Jumlah & 27 & 100 & \\
\hline
\end{tabular}

Pada data tabel 2 menujukan kemampuan kognitif peserta didik pada tes akhir peserta didik 1 peserta didik $(3,70 \%)$ berada pada kualifikasi sangat baik dan 10 peserta didik $(37,04)$ berada pada kualifikasi baik dikarenakan peserta didik berhasil mengerjakan setiap soal tes akhir dengan baik dan benar serta penerapan model pembelajaean NHT (Numbered Heads Together) yang dilibatkan secara langsung dalam setiap proses pembelajaran membuat peserta didik termotifasi dan mau terus belajar dan akhirnya mendapatkan nilai yang baik.

Selanjutnya pencapaian peserta didik yang ada pada kualifikasi cukup berjumlah 10 peserta didik $(37,04)$. Hal ini dikarenakan sebagian peserta didik tidak memahami dan mengerjakan setiap soal 
esai dengan benar, pada esai nomor 1 tentang ikatan ion dan esai nomor 2 tentang ikatan kovalen, peserta didik cenderung mengerjakan soal esai nomor 1 dengan cara pembentukan ikatan kovalen.

Selain itu terdapat 6 peserta didik $(22,22 \%)$ yang berada pada kualifikasi gagal. Hal ini dikarenakan kemampuan peserta didik dalam menyelesaikan setiap soal, peserta didik hanya dapat menyelesaikan sebagian soal dengan benar dan sebagian soal lagi belum mampu peserta didik kerjakan dengan benar dan tidak mengunakan tahapan-tahapan. Yang menyebabkan peserta didik tidak mampu mengerjakan setiap soal karena tingkat kesukaran dari soal tersebut. Terutama pada soal esai tentang pembentukan ikatan ion dan kovalen, ke 6 peserta didik ini cenderung tidak mengerjakan ke 2 soal esai ini. Selain itu peserta didik juga sukar dalam menjawab soal PG nomor 7, 8, dan 9 pada indikator tentang ikatan ion dan ikatan kovalen karena soal pada nomor ini menuntut peserta didik untuk membuat pembentukan ikatan ion, ikatan kovalen, dan ikatan kovalen koordinasi peserta didik tidak mampu mengerjakan soal ini sehingga ke 6 peserta didik ini salah dalam mengerjakan soal ini. Disamping itu, berdasarkan pengamatan, sebagian peserta didik dengan kualifikasi kurang ini termaksud lambat dan kurang termotivasi dalam melakukan kegiatan pembelajaran.

Jika dilihat dari nilai tes akhir dari peserta didik, terjadinya peningkatan hasil belajar dari nilai tes awal, dengan membandingkan nilai tes awal dan tes akhir, maka kita akan dapati bahwa tujuan pengunaan model pembelajaran koopeatif tipe NHT dapat dikatakan bahwa telah tercapai, karena nilai akhir dari proses pembelajaran dari semua peserta didik lebih tinggi dari pada nilai tes awal. Manurung (2013: 6) menyatakan bahwa "peserta didik yang memiliki kemampuan memori rendah dan ketika diajar dengan mengunakan model NHT memiliki banyak kesempatan untuk berdiskusi didalam kelompok-kelompok belajar, sehingg dimungkinkan konsep yang diingat juga lebih banyak".

Tabel 3. Hasil Perhitungan Skor N-gain

\begin{tabular}{|c|c|c|c|}
\hline Interfal & Kategori & Jumlah siswa & Presentase \\
\hline$g>0,7$ & Tinggi & 18 & 66,67 \\
\hline $0,3<g \leq 0,7$ & Sedang & 9 & 33,33 \\
\hline$g \leq 0,3$ & $\begin{array}{l}\text { Rendah } \\
\text { Jumlah }\end{array}$ & $\begin{array}{c}0 \\
27\end{array}$ & $\begin{array}{c}0 \\
100\end{array}$ \\
\hline
\end{tabular}

Berdasarkan Tabel 3 peningkatan hasil belajar peserta didik pada materi ikatan kimia terdapat $18(66,67 \%)$ peserta didik yang ada pada kotegori tinggi dan $9(33,33 \%)$ peserta didik ada pada kategori sedang. Secara keseluruhan, peningkatan hasil belajar peserta didik pada materi ikatan kimia sebesar 0,71 termasuk dalam kategori tinggi.

Dari semua hasil yang diperoleh menujukan bahwa semua peserta didik berhasil memenuhi kriteria penilaian walaupun berada pada kualifikasi yang berbeda-beda. Jika dibandingkan dengan tes awal hasil tes akhir mengalami peningkatan setelah diterapkan model pembelajaran kooperatif tipe NHT (Numbered Heads together) dengan media Flash Player setiap peserta didik mampu menunjukan hasil belajar yang lebih baik.

\section{KESIMPULAN}

Berdasarkan hasil penelitian yang dilakukan dapat disimpulkan bahwa penerapan model pembelajaran kooperatif tipe NHT (Numbered Heads Together) dengan media Flash Player dapat meningkatkan hasil belajar peserta didik SMK Negeri 6 Ambon pada materi Ikatan Kimia. Hal ini terlihat pada hasil belajar peserta didik yang berada pada kualifikasi sangat baik $1(3,70 \%)$. Baik 10 
(37,04\%), Cukup $10(37,04 \%)$, kurang $6(22,22 \%)$. Hasil dari analisis skor gain ternormalisasi ratarata seluruh peserta didik sebesar 0,71 yang berada pada kategori tinggi.

\section{DAFTAR PUSTAKA}

Ika Y. P., Suryadi B. U., dan Sri Mulyani. 2016. Pengaruh Pembelajaran Kimia Menggunakan Metode Kooperatif Numbered Heads Together (NHT) Disertai Tutor Sebaya Dan Team Assisted Individualization (TAl) Ditinjau Dari Kemampuan Memori Terhadap Prestasi Belajar Siswa (Pokok Bahasan Hidrokarbon Kelas X Sma Negeri 3 Boyolali Semester Genap Tahun Ajaran 2014/2015). Jurnal Pendidikan Kimia (Jpk), Vol. 5 No. 1 ISSN 2337-9995. Hal. 22-31

Yussi, Tri, Mohammad. 2014. Pelaksanaan Model Pembelajaran Problem Based Learning (Pbl) Pada Materi Redoks Kelas X Sma Negeri 5 Surakarta Tahun Pelajaran 2013/2014. Jurnal Pendidikan Kimia (JPK), Vol, 3, No, 3, 40-48.

Retnani F. Y., Sukardjo J.S., dan Utomo S. B. 2014. Penerapan Metode Numbered Heads Together (NHT) Disertai Macromedia Flash Untuk Meningkatkan Motivasi Dan Prestasi Belajar Siswa Materi Struktur Atom, Sistem Periodik, Dan Ikatan Kimia Kelas XI IPA 4 SMA Negeri 2 Boyolal Tahun Pelajaran 2013/2014. Jurnal Pendidikan Kimia (JPK), Vol. 3 No. 3, 57-65.

Evi S Bahriah., dan Sella M Abadi. 2016. Motivasi Belajar Siswa Pada Materi Ikatan Kimia Melalui Metode Praktikum. Jurnal Kimia Dan Pendidikan Vol.1, No.1 (86-97)

Latifah., et al. 2008. Peningkatan Hasil Belajar Kimia Siswa SMA dengan Penugasan dan Penilaian Portopolio. Jurnal Inovasi Pendidikan Kimia. Vol. 2(1), 250-254.

Manurung, I.W., Mulyani. B., dan Saputro, S. 2013. Pengaruh Penggunaan Model Pembelajaran Kooperatif Numbered Heats Together (NHT) dan Learning Together (LT) dengan Melihat Kemampuan Memori siswa Terhadap Perstasi Belajar Siswa pada Materi Tata Nama Senyawa Kimia Kelas XSMAN 2 Karanganyar. Jurnal Pendidikan Kimia, 2(4), 24-31. 